\title{
Alberto José Sampaio* Um botânico brasileiro e o seu programa de proteção à natureza ${ }^{1}$
}

\section{Alberto José Sampaio \\ A Brazilian botanist and his nature protection program}

\author{
JOSÉ LUIZ DE ANDRADE FRANCO \\ Doutor em História pela Universidade de Brasília. Assessor Técnico da Diretoria de Áreas \\ Protegidas da Secretaria de Biodiversidade e Florestas, do Ministério do Meio Ambiente \\ jlafranco@aol.com \\ JOSÉ AUGUSTO DRUMMOND \\ Professor Adjunto, Centro de Desenvolvimento Sustentável, Universidade de Brasília \\ jaldrummond@uol.com.br
}

\begin{abstract}
RESUMO O texto discorre sobre a obra científica e as proposições de proteção à natureza do botânico brasileiro Alberto José Sampaio (18811946), um dos maiores conhecedores da flora brasileira e um dos pioneiros do conservacionismo no país. Analisa diversos pontos de sua trajetória de cientista, ativista e professor. A atenção recai especialmente sobre as suas três principais produções literárias, publicadas entre 1926 e 1935, nas quais focaliza a distribuição geográfica dos conjuntos de vegetação do Brasil e propõe diversos programas de aproveitamento racional e de preservação dos recursos naturais brasileiros. Mostra-se que as suas idéias estavam influenciadas pelos ideais de um estado forte capaz de construir uma nova identidade nacional, com base na riqueza da nature-
\end{abstract}

Artigo recebido em: 10/08/2004 - Aprovado em: 18/11/2004.

1 Baseado parcialmente em FRANCO, José Luiz de Andrade, Proteção à Natureza e Identidade Nacional: $1930-$ 1940. Tese de Doutorado, defendida no Departamento de História da Universidade de Brasília. Julho, 2002. 
za brasileira. A conclusão é que as idéias de Sampaio foram avançadas para a sua época e que elas conservam grande parte de sua atualidade, mesmo depois de décadas de prevalência de uma ideologia desenvolvimentista em que ele e diversos cientistas naturais conservacionistas seus contemporâneos foram quase inteiramente esquecidos.

Palavras-chave botânica, conservação da natureza, política ambiental

ABSTRACT The text discusses the scientific output and the proposals for nature protection by the Brazilian botanist Alberto José Sampaio (18811946), one of Brazil's leading plant scientists and one of the country's pioneer conservationists. Several aspects of his trajectory as a scientist, activist and teacher are examined. The emphasis falls on his three major books, published between 1926 and 1935, in which he writes about the geographic distribution of Brazil's vegetational forms and presents many proposals in favor of the rational use and preservation of the country's natural resources. It is shown that his proposals were influenced by the concept of the need of a strong State that could build a new national identity, based on Brazilian nature. The text concludes that Sampaio's ideas were quite advanced for his times and that many of them are still relevant to current environmental issues, even after decades of prevalence of a strong developmentalist ideology in which his ideas and those of his contemporary scientific colleagues were almost totally forgotten.

Key words botany, nature conservation, environmental policy

\section{1 - A Proteção à Natureza no Brasil nos Anos 1930-1940}

Este artigo expõe e analisa as principais contribuições de Alberto José Sampaio para as reflexões e os esforços pioneiros de proteção à natureza no Brasil. Sampaio fez parte de um grupo relativamente coeso, constituído em sua maioria por cientistas, intelectuais e funcionários públicos, que se mobilizou, no Brasil dos anos 1930-1940, em torno de preocupações com a proteção da natureza. Estes atores apoiavam-se em certas linhagens do conhecimento científico sobre o mundo natural e defendiam a idéia de que este mundo merecia ser conservado, por motivos tanto sócio-econômicos quanto estéticos. ${ }^{2}$

2 Cf. sobre o desenvolvimento do conhecimento científico a respeito do mundo natural e sobre uma preocupação com a sua conservação na modernidade os trabalhos de THOMAS, Keith. O Homem e o Mundo Natural. São Paulo: Cia das Letras, 1996; MCCORMICK, John. Rumo ao Paraíso: A História do Movimento Ambientalista. Rio de Janeiro: Relume-Dumará, 1992; WORSTER, Donald. Nature's Economy: A History of Ecological Ideas. Cambridge: Cambridge University Press, 1994; NASH, Roderick Frazier. The Rights of Nature: A History of 
Algumas instituições científicas brasileiras tiveram, neste aspecto, um papel fundamental. A principal delas foi o Museu Nacional do Rio de Janeiro. Ao desenvolver pesquisas voltadas para o estudo da história natural e da antropologia, os cientistas e professores do MN logo despertaram para o problema da destruição do patrimônio natural pelas ações humanas. Vários se dedicaram a um ativismo e à formulação de um pensamento voltados para a proteção da natureza. Entre estes podemos citar: Cândido de Mello Leitão, Paulo Roquette-Pinto, Berta Lutz, Heloísa Alberto Torres, Armando Magalhães Corrêa e o próprio Alberto José Sampaio. Frederico Carlos Hoehne, que teve atuação destacada em São Paulo, começara a sua carreira no MN.

Estes cientistas tiveram intensa atuação individual e junto a grupos cívicos que abraçaram a causa da proteção à natureza. Dentre eles destacam-se o Centro Excursionista Brasileiro, cujos guias eram credenciados como guardas florestais; a Federação Brasileira para o Progresso Feminino, liderada, entre outras, pela bióloga Berta Lutz; a Sociedade de Amigos de Alberto Torres (Armando Magalhães Corrêa foi um de seus fundadores); a Sociedade Geográfica do Rio de Janeiro; a Sociedade de Amigos das Árvores (fundada em 1931, por A. J. Sampaio) e a Sociedade dos Amigos do Museu Nacional (constituída por funcionários do MN). Em São Paulo, Frederico Carlos Hoehne organizou a Sociedade de Amigos da Flora Brasílica, entre cujos sócios-fundadores havia cientistas, funcionários públicos, horticultores e fazendeiros inovadores. ${ }^{3}$

Estas organizações atuaram na proteção da natureza: denunciavam o desmatamento, propunham reformas nas técnicas agrícolas, defendiam a promulgação de uma lei florestal, distribuíam sementes e ministravam palestras. Esses tipos de pressão, aliados à capacidade de aconselhar e influenciar setores importantes da burocracia estatal, foram fundamentais na definição de ações governamentais em defesa do patrimônio natural.

A onda de mobilização, que envolveu organizações da sociedade civil e instituições públicas preocupadas com a conservação da natureza, teve o seu ponto culminante na realização da "Primeira Conferência Brasileira de Proteção à Natureza", entre 8 e 15 de abril de 1934, no Rio de Janeiro. Organizada pela Sociedade dos Amigos das Árvores, con-

Environmental Ethics. Wisconsin: Wisconsin University Press, 1989; PÁDUA, José Augusto. Um Sopro de Destruição: Pensamento Político e Crítica Ambiental no Brasil Escravista (1786-1888). Rio de Janeiro: Zahar, 2002; ACOT, Pascal. História da Ecologia. Rio de Janeiro: Campus, 1990; ALPHANDÉRY, P., BITOUN, P. e DUPONT, Y.. O Equívoco Ecológico: Riscos Políticos. São Paulo: Brasiliense, 1992.

3 Cf. DEAN, Warren. A Ferro e Fogo: História e Devastação da Mata Atlântica Brasileira. São Paulo: Cia das Letras, 1996. Sobre a atuação de Frederico Carlos Hoehne, ver FRANCO, José Luiz de Andrade e DRUMMOND, José Augusto, Frederico Carlos Hoehne: a atualidade de um pioneiro no campo da proteção à natureza, paper apresentado no II Encontro da ANPPAS, Indaiatuba, 2004. 
tou com forte apoio e infra-estrutura do MN. Alberto José Sampaio foi o relator do evento. ${ }^{4}$

Datam desta época a elaboração de uma série de regulamentos relacionados ao problema da proteção da natureza no Brasil — o Código Florestal, o Código de Caça e Pesca, o Código de Águas, o Código de Minas e o Código de Fiscalização das Expedições Artísticas e Científicas, todos publicados entre maio de 1933 e outubro de 1934. ${ }^{5}$ Além disso, a própria Constituição de 1934 encarregava os estados e o governo central de proteger as "belezas naturais" e os "monumentos de valor histórico ou artístico". Poucos anos depois, reafirmando a institucionalização da preocupação com o mundo natural, foram criados os primeiros parques nacionais do país: Itatiaia, em 1937, e Serra dos Órgãos e Iguaçu, em 1939. ${ }^{6}$

É nesse contexto de avanço das preocupações com a questão da proteção à natureza no Brasil que a figura de Alberto José Sampaio adquire relevância. Ele participou dessa virada, tanto pelas suas atividades científicas quanto pela sua capacidade de mobilizar cidadãos e organizações civis e governamentais a favor da causa, ainda muito difusa e pouco legitimada na sociedade brasileira como um todo.

\section{2 - Alberto José Sampaio: dados biográficos e contexto intelectual}

Sampaio nasceu em Campos dos Goytacazes, no estado do Rio de Janeiro, em 1881. Faleceu em 1946, provavelmente no Rio de Janeiro. Em 1905, aos 24 anos de idade, via concurso público, assumiu a função de Assistente de Botânica no MN, instituição em que, a partir de 1912, aos 31 anos de idade, passou a trabalhar como professor e chefe da Seção de Botânica. Trabalhou nesses cargos até 1937. Quando ingressou no MN, interrompeu os seus estudos de medicina, que só veio a concluir muitos anos mais tarde. Por meio do seu trabalho no MN, tornou-se botânico, um dos mais importantes do Brasil de todos os tempos e, talvez, o mais importante de sua época.

Dedicou-se, inicialmente, ao estudo das Orquidáceas, e depois, das

4 Cf. SAMPAIO, Alberto José (relator). Relatório Geral da Primeira Conferência Brasileira de Proteção à Nature-

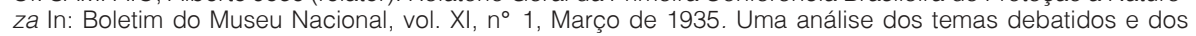
resultados dessa conferência está em FRANCO, José Luiz de Andrade, "A Primeira Conferência Brasileira de Proteção à Natureza e a questão da Identidade Nacional”, In: HORTA, Regina (org.), Varia Historia, , Dossiê História e Natureza, Departamento de História UFMG, Belo Horizonte, № 26 (janeiro de 2002), p. 77-96.

5 Cf. sobre a legislação relacionada à proteção da natureza no período, FBCN. Legislação de Conservação da Natureza. São Paulo: CESP, 1986. PEREIRA, Osny Duarte. Direito Florestal Brasileiro (Ensaio). Rio de Janeiro: Borsoi, 1950. DRUMMOND, José Augusto. "A Legislação Ambiental Brasileira de 1934 a 1988: comentários de um cientista ambiental simpático ao conservacionismo.", In: Ambiente e Sociedade - Ano II - №s 3 e 4 - 2ํㅡㄴ semestre de $1998,1^{\circ}$ semestre de 1999.

6 Cf. sobre a criação e o funcionamento dos primeiros parques nacionais, BARROS, Wanderbilt Duarte de. Parques Nacionais do Brasil. Rio de Janeiro: Ministério da Agricultura, 1952. DRUMMOND, José Augusto. Devastação e preservação ambiental no Rio de Janeiro. Niterói: EDUFF, 1997. 
Filicíneas e das Bignoniáceas. Viajou com Rondon pela região do Cuminá e em 1916 publicou um estudo sobre a flora do Mato Grosso, dedicado aos botânicos integrantes da Comissão Rondon. Nesse estudo, procurou recolher informações constantes de todos os trabalhos realizados por pesquisadores nacionais e estrangeiros naquele estado, o que the possibilitou fazer um mapeamento de todos os componentes conhecidos da flora local, inclusive algas e fungos. Nascia então o seu ambicioso e influente projeto de elaborar uma classificação fitogeográfica de todas as regiões brasileiras. Defendeu, desde 1912, a necessidade de reflorestar áreas desmatadas ou degradadas e a criação de reservas naturais. Foi membro da Academia Brasileira de Ciências, tendo sido o seu Secretário Geral no biênio 1933-1935. Publicava regularmente em diversas revistas de destaque, como a Revista Brasileira de Geografia, a Revista Nacional de Educação, o Boletim do Museu Nacional e os Archivos do Museu Nacional. ${ }^{7}$

As idéias de Sampaio sobre a proteção da natureza vinculavam-se a uma corrente de pensamento nacionalista e desenvolvimentista, a qual vinha ganhando importância no cenário político brasileiro. A sua intenção era institucionalizar medidas relativas ao cuidado com o mundo natural, medidas essas propostas pela geração de cientistas que o precedeu - homens como Alberto Loefgren e Herman Von Ihering -, articulando-as ao projeto de construção da nacionalidade de Alberto Torres, autor para o qual a natureza desempenhava um papel estratégico.

Sampaio teve papel de destaque na concepção da legislação de proteção dos recursos naturais emitida a partir de 1934. Participou, como representante do Museu Nacional, ao lado de Durval Ribeiro do Pinho, presidente da Sociedade dos Amigos das Árvores, da elaboração do Código Florestal. ${ }^{8}$

Foi Sampaio quem formulou, da maneira mais clara e detalhada, um projeto que unia preocupações específicas com o cuidado do mundo natural a idéias relacionadas à "construção da nacionalidade". O seu ponto de partida foi a defesa da efetivação do Serviço Florestal Federal, organizado em 1925. ${ }^{9}$ Dessa questão ele evoluiu até a percepção mais

7 Cf. sobre os dados biográficos de SAMPAIO, A. J.: Cândido de Mello Leitão. A Biologia no Brasil. São Paulo: Cia Editora Nacional, 1937; FERRI, Mário Guimarães. A Botânica no Brasil. In: AZEVEDO, Fernando de (org.) As Ciências no Brasil, vol. 2. Rio de Janeiro: UFRJ, 1994; DEAN, Warren, op. cit. Uma interpretação históricopolítica distinta da obra de Sampaio - além de dados biográficos - constam de CAPANEMA, Carolina Marotta, "Representações sobre Natureza, território e Sociedade: Alberto José de Sampaio e a Fitogeografia no Brasil", XIV Encontro Regional de História da ANPUH-MG. Juiz de Fora, julho de 2004. Ver ainda http:// www.abc.org.br/historia/acadmemoletra.asp?letra $=A$

8 Cf. a esse respeito, PEREIRA, Osny Duarte. Direito Florestal Brasileiro, pp. 131-132.

9 Cf. DEAN, Warren, op. cit. Segundo esse autor: "... A escassez de combustível durante a guerra concentrou temporariamente a atenção na política de conservação e, em 1920, o presidente Epitácio Pessoa, destacando ao Congresso que o Brasil era o único país de florestas sem um código florestal, pressionava pela criação de um Serviço Florestal federal. O decreto implementando o serviço foi emitido em 1925 por seu sucessor. Infelizmente, tudo o que conseguira foi alterar o papel timbrado do viveiro de mudas da capital federal; uma 
abrangente da necessidade de se instituir uma série de iniciativas no campo da proteção à natureza.

Foram as idéias de Alberto Torres, vinculando natureza com a organização e a identidade nacionais, que lhe permitiram formular uma estratégia e um projeto coerentes, em torno dos quais iriam gravitar as iniciativas relacionadas à proteção da natureza. Alberto Sampaio escreveu inúmeros textos em jornais e em revistas especializadas. Numerosos textos de seus cursos e de suas conferências também foram publicados.

Para fins deste artigo, optamos por analisar três obras específicas, que nos parecem expor com mais clareza e amplitude o seu pensamento, inclusive os aspectos que foram sendo reelaborados com o passar do tempo. ${ }^{10}$ Apesar de sua produção literária relativamente vasta e definitivamente pioneira, apesar da divulgação dessa obra por editoras e revistas científicas importantes, apesar de sua atividade mais propriamente ativista, e apesar de ter, como professor, ajudado a formar dezenas de outros cientistas engajados na pesquisa biológica e na questão ambiental brasileiras, Sampaio é hoje pouco conhecido ou francamente esquecido. O mesmo ocorre com vários de seus contemporâneos e colegas de ciência e/ou ativismo, como Frederico Carlos Hoehne, Armando Magalhães Correa e Cândido de Mello Leitão. ${ }^{11}$ Estamos convencidos de que a melhor divulgação das idéias de Sampaio e outros pioneiros da questão ambiental brasileira é relevante não apenas do ponto de vista de uma reconstituição da "genealogia" desse campo de pensamento no Brasil, mas também, da formulação e da tomada de decisões públicas e privadas na atualidade.

\section{3 - O Problema Florestal no Brasil}

A primeira obra a ser analisada, intitulada O Problema Florestal no Brasil em 1926, ${ }^{12}$ é um relatório apresentado ao Congresso Internacional

década depois, fazia pouco mais que transferir mudas para o embelezamento de ruas. O serviço carecia de um orçamento, de um código para aplicar e até de florestas para manter, porque a Constituição republicana havia devolvido todas as terras públicas para os estados. Excepcionalmente, o serviço conseguiu administrar as florestas que protegiam o suprimento de água da cidade do Rio de Janeiro, as quais haviam aumentado, juntamente com a população da capital, para quinhentos km2. O governo federal convocou os estados a doar parte de suas terras de matas para a criação de reservas, sem resultado algum. O Serviço Florestal estava apenas começando a assinar acordos com alguns estados para ajudá-los a financiar seus próprios serviços florestais quando República [Velha] foi derrubada".(p. 272.)

10 Cf. de SAMPAIO, Alberto José. O Problema Florestal no Brasil em 1926. In: Archivos do Museu Nacional, vol. XXVIII, março de 1926; Phytogeografia do Brasil. São Paulo: Companhia Editora Nacional, 1934.' e Biogeographia Dynamica. São Paulo: Companhia Editora Nacional, 1935.

11 Cf. A este respeito FRANCO, José Luiz de Andrade, Proteção à Natureza e Identidade Nacional: 1930-1940. Tese de Doutorado, defendida no Departamento de História da Universidade de Brasília. Julho, 2002. FRANCO, José Luiz de Andrade e DRUMMOND, José Augusto, Frederico Carlos Hoehne: a atualidade de um pioneiro no campo da proteção à natureza, paper apresentado no II Encointro da ANPPAS, Indaiatuba, 2004.

12 Cf. SAMPAIO, Alberto José. O Problema Florestal no Brasil em 1926. In: Archivos do Museu Nacional, vol. XXVIII, março de 1926. 
de Silvicultura, realizado em Roma, em 1926. Tinha o intuito de servir de "propaganda da silvicultura e como contribuição do Museu Nacional aos esforços a serem desenvolvidos pelo Serviço Florestal". ${ }^{13}$ Sampaio pretendia ajudar a construir um programa por meio do qual o Serviço Florestal se responsabilizasse pela pesquisa, pelo controle e pela implementação de florestas produtivas no Brasil. Isso seria fundamental para que o país assumisse uma liderança entre os maiores produtores de madeiras, conservando ao mesmo tempo, o máximo possível de suas essências nativas. ${ }^{14}$

Este posicionamento de Sampaio desmente apreciações hoje já bem disseminadas entre estudiosos e ambientalistas brasileiros de que os cientistas brasileiros desta época pensavam apenas na proteção de plantas e de animais, exibindo insensibilidade quanto aos imperativos da produção e do bem-estar social.

O relatório iniciava-se com a constatação de que, com o desenvolvimento de uma sociedade urbano-industrial e o conseqüente consumo de produtos florestais, as áreas de florestas nativas em todas as partes do mundo tenderiam a diminuir. Assim, os países que mais reflorestassem seriam os que mais lucrariam. O Brasil tinha uma vantagem natural, dado o seu estoque florestal nativo. No entanto, era importante não dilapidar esse estoque e promover, desde cedo, a silvicultura, com o objetivo de garantir a conservação dos recursos do país. Em seu trabalho rotineiro como cientista, Sampaio tentava fazer o levantamento relativamente detalhado das áreas florestais e das essências úteis encontradas no território nacional. Destacava, entre os bens florestais brasileiros produzidos e exportados, a erva-mate, a borracha, as madeiras, fibras, raízes, cascas, ceras e resinas, as castanhas e os cocos - dando um início modesto a uma "bio-prospecção" que ainda hoje, 80 anos depois, ainda está longe de ser minimamente satisfatória.

Entendidas as dimensões dos estoques, dos bens e dos seus usos, Sampaio dava o passo seguinte. Formulou um programa para a efetivação do Serviço Florestal do Brasil, assim justificado:

A boa conservação do patrimônio florestal de cada nação depende justamente da exploração racional das florestas que, se intangíveis, correriam risco de depreciação, à vista do que consegue hoje a silvicultura como valorização. (...) E acresce que a humanidade não pode dispensar a exploração de florestas, mas por isso precisa também que não se destrua a vegetação florestal. (O problema florestal, p.91)

13 Idem, ibidem, p.56.

14 Idem, ibidem, p. 56 
Os objetivos do projetado Serviço Florestal incluíam: a) a criação, a conservação e a guarda de florestas protetoras que, estabelecidas junto às cidades, deveriam beneficiar a higiene e a saúde pública, garantir a pureza e abundância dos mananciais, além de equilibrar o regime das águas correntes; b) a sistematização da exploração das florestas nacionais e o reflorestamento de terras baldias; c) a criação de hortos e florestas modelos; d) a criação de reservas florestais que conservassem, o máximo possível, as características da fauna e flora indígenas; e) a criação e a propagação de conhecimentos relativos à silvicultura; f) a assistência a particulares que desejassem explorar racionalmente os recursos florestais de suas terras ou estabelecer plantios; e g) a reunião de dados que permitissem formar um quadro preciso da situação florestal do país.

Ao compor essa agenda, Sampaio claramente propunha que o Serviço Florestal do Brasil interferisse no laissez-faire a que estavam sujeitas as florestas brasileiras, tanto para racionalizar a produção de bens florestais quanto para permitir o avanço do conhecimento científico sobre as mesmas. O órgão era necessário para promover o que ele chamava de "silvicultura racional". Nela a árvore se apresentava como um fator econômico, ecológico e social relevante para as políticas públicas. Este tipo de silvicultura viria instalar no Brasil florestas industriais homogêneas em que deveriam predominar essências indígenas ou exóticas de rápido desenvolvimento e com bom potencial de aproveitamento industrial. Recorde-se que neste momento o Brasil carecia de leis, incentivos e regulamentos pertinentes a florestas produtivas, contando com uma área irrisória de árvores plantadas para fins produtivos, sobretudo quando comparada com as áreas que estavam sendo desmatadas, naquele mesmo momento, para a expansão da cafeicultura. A expansão das fronteiras agrícolas não apenas consumia enormes trechos de florestas nativas de Mata Atlântica de forma imprevidente, como não contemplava medidas compensatórias de replantios para quaisquer fins, fossem ecológico-ambientais, fossem produtivos.

Sampaio entendia que, além de reservas florestais destinadas a serem santuários ou relicários da flora indígena, a silvicultura teria de meIhorar as florestas nativas, tendendo a reduzir a sua heterogeneidade e a criar florestas artificiais, homogêneas e industriais por excelência. Para tanto, a estratégia de ação do Serviço Florestal do Brasil deveria priorizar quatro pontos fundamentais: 1) cultura racional de "Reservas Florestais", isto é, exploração racional moderada de florestas nativas, com o intuito também de defesa e conservação da flora e da fauna indígenas; 2) exploração racional intensiva de florestas indígenas ou nativas, com replantios, buscando a sua homogeneização; 3) cultura de essências nacionais e exóticas em florestas homogêneas; 4) culturas florestais, de 
bosques e parques, visando uma arquitetura paisagista capaz de trazer os benefícios da salubridade, do conforto e da estética. ${ }^{15}$ Sampaio escrevia em 1926 sobre o que hoje chamamos de florestas nacionais manejadas (ainda fracamente implementadas no país) e de plantios comerciais (expandidas apenas a partir de fins da década de 1960).

Sampaio enfatizou muito neste texto a questão da produção. Ele chamava a atenção para a necessidade de conservar as matas nativas e mesmo para a de criar reservas, mas deu ênfase maior à necessidade de organizar a produção de bens florestais em base racional. Em terminologia moderna, "sustentabilista", ele queria garantir a obtenção de riquezas pelas gerações presentes, sem inviabilizar essa mesma possibilidade para as gerações futuras. A idéia de cidades arborizadas e cercadas por bosques, as "cidades jardins" ou "cidades florestas", figurava entre as suas propostas. Embora houvesse a percepção de que a natureza devia ser preservada, a expectativa maior era que ela pudesse ser melhorada pela ação humana, ampliando o seu rendimento.

No que se refere às reservas florestais, Sampaio explicava que:

Ao Serviço Florestal do Brasil, criado em 1925, caberá promover a formação ou constituição de reservas florestais, promover a criação de parques, isto é, de florestas típicas que conservem, tanto quanto possível, todas as características da fauna e da flora indígena, reflorestar as terras baldias com essências nacionais e exóticas que mais se adaptem às respectivas regiões, tendo em vista estabelecer em cada Estado, no mínimo, uma reserva florestal. ( $O$ Problema Florestal, p. 114)

Havia, pois, preocupação com a fauna e a flora indígenas, mas ela convivia com a idéia "produtivista" mais forte de reflorestamento, inclusive com espécies exóticas. Sampaio defendia, baseado no rendimento anual médio das florestas cultivadas da Europa, que a área florestada de cada município brasileiro fosse de um terço do seu território, o que possibilitaria que cada cidade se tornasse uma "cidade floresta". A intenção era tornar cada região auto-suficiente em recursos florestais, além de bem aquinhoada do ponto de vista do clima, dos mananciais, da saúde e das paisagens.

Sampaio elogiava as experiências que Edmundo Navarro de Andrade vinha desenvolvendo em São Paulo, desde 1904, nos hortos florestais da Companhia Paulista de Estradas de Ferro. Andrade se tornara a principal autoridade na aclimação e no plantio do eucalipto no Brasil, realizando também experiências de plantio com essências nativas. A respeito dessas iniciativas, Sampaio comentava que:

15 Idem, ibidem, pp. 95-96 
O Serviço Florestal da Companhia Paulista de Estradas de Ferro, tendo especialmente por fim satisfazer as necessidades da Companhia quanto a produtos florestais (madeiras de construção e de obra, dormentes, postes, lenha, etc.), mas com margem também a grandes suprimentos a estranhos, constituiu-se desde logo o precursor da Silvicultura Racional no Brasil, como um campo experimental rigorosamente técnico e que faz irradiar por todo país, em ampla divulgação, os ensinamentos adquiridos. (O Problema florestal, p.98)

Havia outras experiências no campo da silvicultura, realizadas tanto por particulares quanto pelos governos municipais, estaduais ou federal. Sampaio propunha que, em um futuro próximo, o Serviço Florestal do Brasil coordenasse todas essas iniciativas. A perspectiva era de que a silvicultura fosse uma função simultânea do Estado e de particulares, produto de um processo de evolução da extração florestal que, repondo as suas matérias primas, deixaria para trás o empirismo. No entanto:

... mesmo então, não é a reconstituição integral da flora primitiva que se processa, mas sim a silvicultura econômica que tem em vista obter, no menor prazo possível, os mais abundantes e os melhores produtos florestais possíveis, à custa de uma flora adventícia, por impossível o mesmo resultado econômico, com a cultura exclusiva da flora indígena de cada região. E então, os botânicos, visando estudos biológicos e a conservação de conjuntos florísticos naturais não muito afastados, indispensáveis a estudos especulativos e ao ensino da Botânica, passam a ser forçados a ... chamar a atenção geral, no sentido de evitar que se extinga por completo a flora primitiva. (O Problema Florestal, p.136)

Surgia, por isso, a necessidade de se criar reservas florestais que garantissem a sobrevivência de exemplares da fauna e da flora nativas. Como exemplos, Sampaio citava a reserva florestal da Tijuca, criada ainda no tempo do Imperador Pedro II, com o propósito de proteger as nascentes que abasteciam o Rio de Janeiro; ${ }^{16}$ a Reserva Florestal do Território do Acre; a do Itatiaia, criada por iniciativa de Alberto Loefgren e administrada como uma estação de pesquisa pelo Jardim Botânico do Rio de Janeiro; e a do Alto da Serra, em São Paulo, criada por Herman Von Ihering e a cargo, então, da seção de botânica do Museu Paulista, dirigida por Frederico Carlos Hoehne. Sampaio menciona Hoehne em virtude de sua campanha, por intermédio de artigos publicados na imprensa, em defesa da Floresta do Jabaquara, na cidade de São Paulo.

Neste momento, no entanto, a questão das reservas ainda não tinha um papel central no pensamento de Sampaio, que privilegiava a questão do reflorestamento. A esse respeito, ele sustentava uma interessante

16 Cf. sobre a Floresta da Tijuca. DEAN, Warren, op. cit; DRUMMOND, José Augusto. Devastação e Preservação Ambiental no Rio de Janeiro.

138 VARIA HISTORIA, $\mathrm{n} \div 33$ 
teoria sobre os estágios históricos do problema florestal, que seriam três: 1) época primitiva, caracterizada pelas derrubadas sem replantio, enquanto existissem matas acessíveis; 2) época de transição, caracterizada pelos primeiros plantios florestais, em terrenos baldios, perto dos centros consumidores, determinados por escassez, cada vez mais severa, de produtos florestais, que tendiam a vir de mais longe e a custar mais caro; 3) predomínio das florestas artificiais, econômicas ou industriais, com tendência à homogeneidade, planejadas para obter o máximo de rendimento; nesta fase a indústria extrativa se concentraria nas florestas artificiais, que têm sobre as florestas nativas, longínquas, a vantagem de estar perto dos centros consumidores e dos portos de embarque. ${ }^{17}$ Este esquema interpretativo revela o seu conhecimento de uma vasta literatura internacional que tratava da garantia de oferta de madeira, principalmente em países ricos que tinham desmatado os seus territórios de maneira irracional em passados ainda recentes. Devido à dinâmica do avanço de sucessivas fronteiras madeireiras e agrícolas, o esquema interpretativo de Sampaio pode ser usado até hoje no Brasil — com as devidas adaptações - para estudos regionais sobre a oferta e o consumo de produtos madeireiros.

Sampaio pensava que o recém-criado Serviço Florestal do Brasil seria o principal elemento de coordenação de um processo de transição do extrativismo empírico de florestas nativas ao aproveitamento sistemático de florestas homogêneas. Uma nova era, marcada pela "Silvicultura Racional", levaria o Brasil a se tornar um "centro de prosperidade mundial". Neste particular, Sampaio foi otimista demais. Quase meio século se passaria até que, na década de 1970, programas de plantio comercial de árvores e os respectivos incentivos fiscais começassem a estimular os plantios sistemáticos e em grande escala que transformaram o Brasil numa potência mundial de produtos madeireiros baseados em matéria prima plantada. Além do mais, foi a iniciativa privada a principal responsável por isso, e não o setor público, cujas florestas de produção (Florestas Nacionais) infelizmente têm até hoje uma importância comercial mínima. De toda forma, o IBDF, criado em 1966, como uma espécie de "filho" institucional e modernizado do Serviço Florestal do Brasil, de fato teve uma participação técnica importante no lançamento da era de plantios florestais racionais, estabelecendo critérios e aprovando planos de plantio comercial de árvores elegíveis para benefícios de incentivos fiscais.

17 Cf. SAMPAIO, Alberto José. O Problema Florestal no Brasil em 1926, p. 137. 


\section{4 - Da Silvicultura Racional à Proteção da Natureza}

Outra obra de Sampaio, Phytogeographia do Brasil, ${ }^{18}$ se baseava nas aulas de um curso oferecido no Museu Nacional do Rio de Janeiro, em 1932. Essas aulas foram publicadas originalmente, em partes, no "Suplemento llustrado" do jornal carioca Correio da Manhã, em 1933, com ilustrações de Armando Magalhães Corrêa. Esse material, com o acréscimo de algumas notas explicativas, foi transformado em livro, publicado, em 1934, pela prestigiosa Companhia Editora Nacional, na sua coleção "Brasiliana".

O autor assim esclarecia o seu objeto:

No curso de Geografia Botânica, em 1932, no Museu Nacional, tratei especialmente do "Patrimônio Florístico do Brasil", tendo também em vista a Biogeographia Dynamica, para a proteção à natureza já muito devastada e que, segundo Alberto Torres, Euclydes da Cunha, Manoel Bomfim e outros, tem sido saqueada, no que teve e ainda tem de mais precioso. (Phytogeographia..., p.11)

Vê-se que o conceito de proteção à natureza começava a assumir importância no seu pensamento. Doravante, ele sobrepujaria a idéia de silvicultura racional. Nessa perspectiva, as essências nativas e, principalmente, o conjunto formado pela fauna e pela flora, ganharam destaque. Sampaio procurou legitimar a proteção da natureza inserindo-a no curso de uma tradição. A esse respeito, Sampaio citava a sua obra anterior e discorria sobre a personalidade e a obra de José Bonifácio, o "patriarca da independência", para definir a situação do homem frente ao mundo natural no Brasil:

No relatório que apresentei ao Congresso Internacional de Silvicultura de Roma, sobre "O Problema Florestal no Brasil em 1926", tive ocasião de divulgar uma longa bibliografia sobre o assunto e pela qual se verifica que há mais de um século se desenvolve em nosso país a campanha defensiva de nossa flora, salientando-se no começo do século passado José Bonifácio de Andrada e Silva, o Patriarca...(Phytogeografia, p. 18)

Bonifácio e Alberto Torres influenciaram muito Sampaio. Eles defendiam o desenvolvimento, no Brasil, de uma civilização baseada em uma relação estreita do homem com a terra. Seria uma sociedade de pequenos agricultores, instruídos, aplicando técnicas modernas de cultivo, vivendo em harmonia com a "pródiga" natureza que herdaram, respeitando e conservando os recursos naturais para as gerações vindouras. Os principais pontos a atacar eram a imprevidência, a ignorância e o egoís-

18 Cf. SAMPAIO, Alberto José. Phytogeographia do Brasil. 
mo. Havia, portanto, a necessidade de se organizar uma "cruzada" para instruir e dar ao homem do campo condições de realizar a utopia. Pretendendo contribuir para essa tarefa, Sampaio explicava que:

... o presente curso é feito para integrar o assunto na instrução nacional; é preciso que a opinião pública, convenientemente esclarecida, facilite aos técnicos o desenvolvimento dos trabalhos que Ihes competem, de proteção á natureza, isto é, 'conduza a fazer e deixe fazer', como disse Alberto Torres; cada pessoa deve no caso realizar, deixar realizar e ajudar a realizar, porque cada cidadão tem parte, pelo menos moral, da responsabilidade, na destruição que se opera no Patrimônio Natural do Brasil.(Phytogeografia, p.13)

A autoridade estrangeira também era chamada a fortalecer a argumentação. O professor Derscheid, Secretário Geral do Ofício Internacional de Proteção à Natureza, teria declarado que "essa proteção não se realiza, senão sob a 'pressão forte da opinião pública', isto é, quando todo mundo reconhece a necessidade, clama e exige essa proteção, agindo, além disso, cada cidadão em favor da natureza, por palavras e atos concretos, em cada oportunidade."19

Era necessário, portanto, esclarecer e mobilizar a opinião pública. Os escoteiros deveriam ajudar nesse processo, bem como as escolas, ambos incumbidos da tarefa de conscientizar a sociedade para a necessidade de proteger a natureza. Sampaio justificava até mesmo o uso da força:

O senhor Mussolini, tendo em conta essa pressão forte da opinião pública na Itália, como salientada por Piccioli, em seu livro 'Silvicultura', tomou a si impulsionar a proteção à natureza em seu país; e reconhecendo a necessidade de rígida disciplina e continuidade, militarizou o serviço [florestal] italiano e deu-Ihe um chefe general. (Phytogeografia, p. 15)

A salvaguarda do "patrimônio natural" estava acima dos interesses particulares dos indivíduos. A natureza, erigida em utilidade pública e objeto de culto, teria a sua proteção motivada por objetivos que eram, ao mesmo tempo, econômicos, estéticos e sociais:

Quer isso dizer que há, no estudo da flora, uma parte, a Agronômica, compreendendo silvicultura, em especial econômica, competindo a Ministérios da Agricultura; e outra parte educacional, de defesa da natureza e Monumentos Naturais, competindo a Departamentos de Educação; basta lembrar que a Arquitetura Paisagística compete a Escolas de Belas Artes e que as Universidades tendem todas a manter "Estações Biológicas", para estudos originais. (Phytogeografia, p.13)

19 Idem, ibidem, pp. 13-15 
Como adiantado acima, Sampaio apostava na possibilidade de desenvolvimento de uma silvicultura racional aliada à proteção de áreas de reserva. A natureza deveria ser preservada tanto por motivos utilitários, quanto pela sua beleza. Para ele, parecia absurdo pensar na flora como fonte inesgotável de recursos. Tal presunção estaria levando a uma redução das zonas florestais em todo o mundo. Por outro lado, achava despropositada a pretensão de voltar ao antigo "coeficiente florestal" do país, cujo desbravamento fora necessário para estabelecer as cidades, a agricultura, a pecuária e as indústrias em geral. Para ele, bastaria que se ficasse na "justa medida", mantendo-se "racionalmente": 1) florestas protetoras de mananciais; 2) florestas, na razão de 40\%, nas áreas agrícolas, para manterem as condições climáticas favoráveis às culturas; 3 ) florestas e parques de conforto climático, nas cidades, na razão de 20 a $25 \%$ da área urbana; 4) florestas naturais, de paisagem, no habitat rural, servindo de fonte de alimentação via coleta e caça; 5) florestas econômicas ou de rendimento, para corte, isto é madeira, lenha, carvão etc. ${ }^{20}$

Ele considerava necessário conhecer melhor as regiões florísticas do Brasil para que a proteção à natureza ocorresse com conhecimento de causa, Tentou contribuir para essa tarefa na maior parte da Phytogeographia do Brasil. Não cabe fazer aqui uma resenha detalhada dos seus estudos de geografia botânica, mas é importante compreender o que eles esclarecem dentro do contexto científico brasileiro da época e do tipo de preocupação com o mundo natural corrente.

Examinando os nomes dos estudiosos dos diversos ramos citados nas páginas da Phytogeographia, percebemos a erudição e a atualização bibliográfica dos conhecimentos de Sampaio. São citados, entre outros, Humboldt, Martius, Endlilicher, Eichler, Urban, Candolle, Engler, Warming, Schimper, Drude, Flahault, Clements, autores que trabalharam no desenvolvimento da fitogeografia e da ecologia. A discussão de noções como as de clímax, biocenose e sociologia vegetal também indica a atualização de Sampaio com o que de melhor se produzia no mundo. ${ }^{21}$

Já as referências de Sampaio a nomes como os de Francisco Freire Alemão, João Barbosa Rodrigues, Alberto Loefgren, Herman von Ihering, Frederico Carlos Hoehne e Emílio Goeldi indicam um intercâmbio entre instituições de pesquisa científica brasileiras, como o próprio Museu Nacional, o Jardim Botânico do Rio de Janeiro, o Museu Paulista, o Instituto Biológico de São Paulo e o Museu Paraense Emílio Goeldi (Belém). A circulação de idéias e o debate científico contribuíram para o surgimento de preocupações com o cuidado do mundo natural. Em boa medida, eram esses homens de ciência que estavam se mobilizando e produzindo sentidos em torno da idéia de proteção à natureza. Muitos

20 Idem, ibidem, p. 21.

142 VARIA HISTORIA, $n \div 33$ 
dos seus argumentos legitimavam-se a partir das suas práticas científicas. Afinal, a natureza devia ser preservada, também, pelo seu interesse científico.

No caso de Sampaio, tratava-se de uma ciência de inspiração romântica, ${ }^{22}$ na medida em que ele se interessava pelos elementos integrativos. Mesmo os valores relacionados à utilidade ou à individualidade eram integrados em um todo maior, compreendido como uma realidade orgânica. A aventura do conhecimento devia envolver, além da aplicação dos métodos científicos, uma sensibilidade estética. Assim, Sampaio fazia suas as palavras de Humboldt: "É mister que a Poesia se alie à Ciência e que esta se eleve até a Poesia!" ${ }^{33}$ Esta perspectiva romântica era comparável ao que outros cientistas brasileiros da época, preocupados com a proteção da natureza, como Frederico Carlos Hoehne, defendiam:

Essa vida, - harmonia e beleza - , surge em todos os recantos, nos ensolarados e sombrios, e traduz, em cada ambiente, uma finalidade que, — aparentemente egoísta, por natureza exercida com requintado e insofismável desejo de alijar e excluir rivais e comparsas, — resulta no maravilhoso entrosamento de interesses, que, em realidade, é a energia universal mantenedora de todas as coisas e de todas as espécies, causa do equilíbrio, que ao observador arguto não escapa. ${ }^{24}$

Embora admitisse que as especializações eram necessárias ao desenvolvimento da ciência, Sampaio chamava a atenção para a importância, ainda maior, da cooperação espontânea, sincera e desinteressada entre cientistas. Para ele, a cooperação deveria extrapolar os campos da ciência para fazer do país, em harmonia com a natureza, um todo orgânico: "Nada de egoísmos; tudo pelo Brasil". ${ }^{25}$

Essa perspectiva permitia que se delineasse em torno do ideal de proteção à natureza um projeto de nação que unia indissoluvelmente o homem ao mundo natural. A Phytogeographia do Brasil descreve os aspectos da flora do país em sua inter-relação com o clima e o solo, os diversos tipos de vegetação e a inserção do homem em cada região. Assim "cada tipo é para a Ecologia uma vegetação-clímax, isto é, corresponde às condições do solo e do clima; em várias regiões já está modificada pelo homem e pode ser sempre muito melhorada". 26

21 Cf. sobre os desenvolvimentos da fitogeografia e da ecologia ACOT, Pascal, op. cit.; WORSTER, Donald, op. cit.

22 Cf. a esse respeito GUSDORF, Georges. Le Savoir Romantique de la Nature. Paris: Payot, 1985; Franklin L. Baumer. O Pensamento Europeu Moderno, Vols. I e II. Lisboa: Edições 70, 1990.

23 Cf. SAMPAIO, Alberto José. Phytogeographia do Brasil, p. 274.

24 Cf. HOEHNE, Frederico Carlos. Iconografia de Orchidáceas do Brasil. São Paulo: Indústrias Gráficas F. Lanzara, 1949

25 Cf. SAMPAIO, Alberto José. Phytogeographia do Brasil, p. 275.

26 Idem, ibidem, p. 44. 
Sampaio, seguindo uma versão ligeiramente modificada do sistema de Engler, propunha a divisão da flora brasileira em duas grandes províncias: 1) Flora Amazônica ou Hiléia Brasileira; 2) Flora Extra-Amazônica ou Geral. Defendia, também, que "os campos formam o fundo cartográfico de nossa flora; interrompendo os campos aqui e ali, e em grandes extensões, temos a flora amazônica, os cocais, as caatingas, as florestas do litoral, as matas de araucária e a vegetação marítima, tudo na dependência do clima, em especial das chuvas, mas também do solo." 27

Sampaio descreveu de forma detalhada as duas províncias, as suas regiões, os tipos de vegetação e a sua distribuição. As principais essências e plantas e as suas características e utilidades são estudadas de acordo com as suas regiões de ocorrência. Na Flora Amazônica, prevaleciam as florestas, com ocorrência de campos e de um tipo bastante específico de caatinga, no rio Negro. Eram reconhecidas duas zonas, do alto e baixo Amazonas, e duas sub-zonas para cada zona, correspondendo aos lados sul e norte do rio. No entanto, "entre as chamadas zonas amazônicas as diferenças são sutis, pois, quer no Alto quer no Baixo Amazonas, são por igual, características as matas de terra firme, as matas de várzea e os igapós." 28

Sendo essa região pouco explorada pelo homem, Sampaio esclarecia que o seu valor econômico não era, ainda, passível de avaliação exata, não se devendo ir, sem precaução, "tirando o que houver, pois assim será destruir um patrimônio, a conservar permanentemente para as gerações futuras, e melhorando como conveniente." ${ }^{29}$ Advertia que, embora o valor das matas amazônicas fosse incalculável, "à maneira das minas de ouro, carecem de exploração racional, sem esgotamento e mediante culturas, a um tempo compensadoras e visando melhoramentos, de acordo com os ensinamentos da genética vegetal aplicada à Silvicultura." 30

No que se refere à Flora Geral, eram consideradas seis zonas: 1) Zona dos Cocais ou do Meio Norte; 2) Zona das Caatingas ou do Nordeste; 3) Zona das Matas Costeiras ou das Florestas Orientais, já muito devastadas; 4) Zona dos Campos (cerrados), que dá propagações ou disjunções a todas as demais zonas, inclusive à Flora Amazônica; 5) Zona dos Pinhais ou da Araucária; 6) Zona Marítima. ${ }^{31}$

A Zona dos Cocais se localizava principalmente no Estado do Maranhão e parte do Piauí. Caracterizada basicamente por concentrações de

\footnotetext{
27 Idem, ibidem, p.38.

28 Idem, ibidem, p. 50

29 Idem, ibidem, p. 72

30 Idem, ibidem, p. 73.

31 Idem, ibidem, pp. 85-86.
} 
palmeiras - babaçuais, carnaubais, buritizais e açaizais; ocorriam também os campos cerrados, caatingas, areais, flora hidrófila de lagoas, lagos e rios, matas ciliares e mesmo floresta amazônica. Era uma zona de transição entre a Amazônia e o Nordeste. Sampaio destacava as possibilidades de utilização econômica dos diversos tipos de palmeiras e o fato de haver ainda muito a pesquisar a respeito desta zona.

Quanto à Zona das Caatingas, correspondia aos estados do Nordeste, estendendo-se por algumas áreas do Centro e Sudeste. Segundo Sampaio, esta zona:

É uma das mais difíceis de descrever, pela variedade de associações vegetais, desde as florestas outrora luxuriantes e hoje muito devastadas, até as caatingas mais pobres que aí se encontram e que em grande parte resultaram da obra nefasta do homem que há quatro séculos vem destruindo imprevidentemente a vestimenta florística da região. (Phytogeografia, p. 102)

Sampaio considerava o problema das secas e da fome no Nordeste uma questão nacional complexa. O problema exigia obras de açudagem e irrigação, além de continuidade e perseverança. Era um problema, em grande parte, causado pelo próprio homem, que há séculos vinha, por meio de uma lavoura empírica e imprevidente, esgotando os terrenos.

Sampaio menciona diversas espécies de plantas úteis nativas dessa zona, que deveriam ser plantadas em larga escala: umbu, cajá-mirim, juazeiro, maniçobas, mandiocas, juremas, aroeira, oiticica, carnaúba, mangaba etc. Eram referidas também as regiões de brejo, onde existem fontes permanentes de água e que por isso resistiam à seca, servindo mesmo de refúgio aos retirantes. Portanto, caberia expandir esse tipo de refúgio, por meio de obras de irrigação e açudagem, possibilitando "multiplicar aí, tanto quanto possível e conveniente, as espécies florestais, fazendo-as retomar seu lugar às caatingas invasoras que, aliás, por inveteradamente xerófilas, não melhoram de aspecto quando invadem terreno bom." 32 Ele se preocupava, também, em manter a diversidade florística, pois mesmo "quando a irrigação tiver beneficiado toda a região das secas, será então momento de evitar que desapareçam por completo as caatingas, porque algumas pelo menos deverão ser conservadas, como reservas históricas." 33

Outra zona preocupante, pela devastação de suas florestas, era a das Matas Costeiras (que hoje chamamos de Mata Atlântica). Elas ocorriam ao longo do litoral, formando uma faixa de largura variável, esprai- 
ando-se, também, sertão adentro, na forma de matas ciliares ou capões de mato. Sampaio explicava que "hoje as florestas costeiras estão muito reduzidas, o que se explica com o desbravamento necessário à penetração dos colonizadores..." 34 Para além disso existiam, porém, a imprevidência, a agricultura e as aglomerações rurais que se deslocavam na trilha das derrubadas, deixando atrás de si a desolação. A cultura do café era um exemplo vivo deste tipo de atitude, pois que "ainda se encontram velhos cafeeiros nas matas secundárias do Rio de Janeiro, testemunho de antigas culturas de café que, sempre na esteira das derrubadas, através das serras, atingiram São Paulo, onde estão hoje nos confins do noroeste, deixando atrás terras exaustas ou cafezais em declínio."35

Sampaio indicava soluções adotadas recentemente na Itália e França, como o estabelecimento de reservas de fauna e flora e o reflorestamento racional. A proteção da natureza deveria, portanto, se converter em uma prioridade social:

Estando hoje mais ou menos devastada grande parte das florestas no mundo, os geógrafos e biologistas em geral, os economistas, urbanistas, paisagistas, os clubes de turismo, de caça, etc., estão desenvolvendo grande atividade, na proteção de florestas remanescentes e na reconstituição de outras, até mesmo com simples intuito paisagista ou de adorno de paisagens, para fins turísticos (estética rural e urbana). (Phytogoegraphia, p. 140-141)

Sampaio reconhecia, porém, que ocorriam no Brasil algumas iniciativas positivas e defendia um empenho maior dos poderes públicos:

No Brasil já temos serviços florestais, federais, estaduais e municipais e já se executam reflorestamentos; um dos mais belos exemplos é o de Archer, reflorestando a Tijuca, por ordem do Barão do Bom Retiro; a Tijuca que quase chegou a ser morro pelado, foi replantada por Archer e Escragnolle Taunay..., mas de um modo geral a iniciativa privada tem feito muito mais; assim o exemplo de Navarro de Andrade e da Companhia Paulista. (Phytogoegraphia, p. 143)

Além dos argumentos utilitários, Sampaio defendia as matas litorâneas com base em considerações estéticas e na idéia de comunhão com a natureza:

Basta dizer que ainda mesmo no caso de produtos florestais serem completamente dispensáveis, o que não parece provável, precisamos ter florestas, defender as florestas, reconstituir florestas, já pelo simples motivo de serem

34 Idem, ibidem, p. 140

35 Idem, ibidem, p. 148.

146 VARIA HISTORIA, $n \div 33$ 
bonitas em sua majestade; compreende-se que só esta razão basta para vencer os dendroclastas! (Phytogeographia, p. 153)

No sul do Brasil, as matas costeiras entravam em contato com os "pinhais", configurando a Zona da Araucária (hoje classificada com uma parte da Mata Atlântica). Nesta:

Os pinhais típicos, de Paraná, Santa Catarina e Apiaí em São Paulo, encerram, como elementos também típicos, grande quantidade de imbuia, erva mate, tapinhoãs e outras canelas, araçás, guaiuviras, guaraiuvas, etc., sendo também muito característicos os pinheirinhos ou pinheiros bravos, o "assucará", a guabiroba e o branquilho. ${ }^{36}$ (Phytogeographia, p. 161)

As devastações vinham ocorrendo, também, nesta região, devido principalmente à exploração imprevidente da araucária e da imbuia. Sampaio inquietava-se com o fato de que componentes nobres da flora brasileira estavam sendo destruídos, ficando em seu lugar a "escória" da vegetação primitiva, quando não de vegetação invasora, de pouco valor. Havia uma preocupação com o problema da diversidade da flora:

Já Vidal de La Blache salientou muito este fato, de se destruir por toda parte, no mundo, a vegetação nativa e permitir assim a predominância de elementos florísticos de menor valor, acarretando uniformidade da flora em toda parte, com enorme prejuízo para a diversidade da paisagem que é, sem dúvida, um grande atrativo para o turismo, por exemplo. (Phytogeographia, p. 164)

A mesma preocupação aparece na análise da Zona dos Campos (cerrados). Sampaio acreditava que "civilizar os campos, melhorá-los a cada passo, livrá-los da rusticidade bruta e hostil, é o objetivo da civilização que a pouco e pouco se vem infiltrando no hinterland de cada país novo, para aí possibilitar grandes massas de população rural, próspera e feliz". No entanto, ponderava que "não se deve prejudicar o fácies florístico natural de cada região, a ponto de implantar por toda a parte a uniformidade da paisagem." A esse respeito, ele chamava a atenção para a riqueza e diversidade da flora dos cerrados, pois ocuparia mais que toda a "vida de um botânico o estudo da flora de um grande campo, onde não obstante a aparência de uma vegetação igual e monótona, há um grande número de espécies, em geral de pequeno porte, herbáceas ou arbustivas em maioria." 37

Sobre os cerrados, Sampaio argumentava, ainda, que, de uma maneira geral, eles se apresentavam como savanas (campos arborizados)

36 Idem, ibidem, p. 161.

37 Idem, ibidem, pp. 165-166, 182 
ou campinas (campos sem árvores). Pela sua própria dispersão por todas as regiões do país, havia particularidades florísticas e endemismos em cada uma delas.

Por fim, a Zona Marítima, que se estendia desde o Cabo Orange, no Pará (atualmente, no Amapá), até ao Arroio Chuí, no Rio Grande do Sul, compreendia a flora litorânea, além das ilhas costeiras e das afastadas, e da flora marinha. Destacavam-se nessa zona os manguezais, as restingas, a vegetação das praias e dunas, e as ervas, algas e plâncton que compunham a flora dos mares. Sampaio indicava uma série de plantas úteis que proliferavam nesta zona, como sargaço, alga marinha usada como fertilizante; mangue vermelho, pelo tanino; poaia da praia, pelo valor medicinal; caju, pitanga, araçás, almecegas, mandacarus, bacupari, guapeba etc., pelo valor alimentar; além da amendoeira e do coqueiro da Bahia, plantas exóticas aclimadas com sucesso. Chamava a atenção para a pecuária, atividade que se desenvolvia favoravelmente nas regiões praianas, embora alertasse para o fato de que, ali também, ocorrera devastação. 38

Como se vê, Sampaio forneceu uma "geografia vegetal" brasileira bastante fiel, considerando o nível de conhecimento existente na época, a dificuldade de organizar expedições científicas e o fato de ainda haver extensas porções do território nacional esparsamente habitadas pelos não-indígenas. Embora nas décadas seguintes tenha havido avanços na classificação regional da flora brasileira, principalmente com a ajuda de imagens de sensoriamento remoto e de um maior volume de trabalho de campo, a síntese de Sampaio se revelou de alta qualidade e contribuiu muito para as sínteses posteriores.

Nesta Phytogeographia do Brasil, o conceito de proteção à natureza foi elaborado a partir de uma perspectiva que procurava integrar o homem com o seu meio. A idéia fundamental era de que a uma natureza pródiga corresponderia um homem intrinsecamente bom, o brasileiro, em especial o sertanejo. Este necessitava, porém, de maior assistência por parte de um poder público forte, que lhe possibilitasse uma formação moral e uma capacitação nos conhecimentos técnicos e científicos, necessários para que ele estabelecesse uma relação produtiva e previdente com os recursos naturais de que dispunha. A proteção à natureza, portanto, deveria garantir a conservação das matas por meio da implementação de reservas e do incremento da produção madeireira a partir da adoção de métodos racionais.

38 Idem, ibidem, p. 208. 


\title{
5 - A Dinâmica da vida e da proteção à natureza, segundo Alberto José Sampaio
}

Alberto Sampaio publicou Biogeographia Dynamica em 1935, pouco depois da instituição de várias leis de proteção da natureza pelo governo de Getúlio Vargas. O texto abria com o registro otimista de:

\begin{abstract}
... um ambiente eminentemente favorável ao desenvolvimento de meus despretensiosos estudos sobre o assunto, estudos cuja finalidade dinâmica depende precipuamente da divulgação, amparada e animada pelos nossos educadores, fiz preliminarmente, como meu dever, um detido exame retrospectivo da ambientação do tema em nosso país e folgo em declarar que desde a Escola Primária até às Academias e aos Institutos científicos e técnicos, na imprensa, no livro, nas produções literárias e artísticas, nas cátedras e em realizações de vulto, estava feita a terraplanagem da 'Proteção á Natureza no Brasil'. (Biogegraphia Dynamica, p. 8)
\end{abstract}

Sampaio queria legitimar o movimento de proteção à natureza, situando-o em uma tradição que abarcava personalidades ilustres, dentre as quais, cita logo na introdução, o Bispo Azeredo Coutinho, José Bonifácio, Auguste Saint-Hilaire, Porto Alegre, Coelho Neto, Afonso Arinos, Euclides da Cunha, Leôncio Corrêa, Roquete Pinto, Gustavo Barroso e, com especial reverência, Alberto Torres.

Dessa forma, se a proteção à natureza era um assunto que já havia despertado a atenção de setores importantes da sociedade brasileira, tratava-se agora, para Sampaio, de formular um programa efetivo que garantisse a sua realização.

A biogeografia dinâmica, ciência que estudava a interdependência dos seres vivos, ou seja, a biocenose, deveria ser o ponto de partida, segundo Sampaio, para um entendimento acurado das "nossas coisas" e das "nossas gentes", e para a realização de um programa efetivo de proteção à natureza. Esse programa teria por base uma estrutura triangular: 1) a tecnologia, realizadora; 2) a educação, orientadora; 3) a força, como garantia das realizações e defensiva do patrimônio natural remanescente, garantia da ordem. ${ }^{39}$

Essa perspectiva objetivava uma integração maior do homem com o mundo natural. Essa integração deveria ser alcançada principalmente por meio de uma educação que possibilitasse a circulação das informações necessárias à utilização racional dos recursos naturais, bem como a formação de valores éticos que ensinassem o respeito e o amor pela natureza. Em última instância, a força devia garantir a preservação do patrimônio nacional, até que a cultura pudesse prevalecer em um "país

39 Idem, ibidem, pp. 14-15 
novo" como o Brasil. Era preciso que fosse movida uma "cruzada", com "método" e "segurança", para formar o homem e melhorar a terra. O livro de Alberto Sampaio, cujo projeto era o de ajudar a traçar um programa de proteção à natureza, dividia-se em duas partes:

\begin{abstract}
... estudando na primeira o ambiente atual, já muito propício à explanação do assunto, mas ainda hesitante, quanto a iniciativas; na segunda parte, será esboçada a metodologia da disciplina que se convencionou chamar "Proteção à Natureza", para facilidade maior da vulgarização de seus preceitos; como disciplina, tem cientificamente seu lugar na Biogeografia, como feição dinâmica ou aplicada. (Biogeographia, pp. 17-18
\end{abstract}

Sampaio expõe a seguir um extenso programa que, sem anacronismo, podemos batizar com a expressão contemporânea "educação ambiental". Na primeira parte, intitulada "Ambiência", há seis capítulos. O primeiro, "Letras e Artes", traz extensa galeria de nomes e obras no campo da poesia, da prosa e das artes plásticas, nos quais se manifesta, de diversas formas, a preocupação com o mundo natural. As letras e as artes desempenhariam um papel relacionado à "ambientação popular da proteção aos bens naturais, em cada país, falando à alma de toda gente, criando a mentalidade, integrando no subconsciente do povo a noção básica: 'a vida é função do meio'; se melhorarmos o ambiente, ipso facto melhoraremos a nossa existência." 40

Não bastava uma produção no campo das ciências, das letras e das artes focalizada no mundo natural. Era preciso que ela circulasse e atingisse todos os recantos do país. O segundo capítulo trata, portanto, do "Movimento Educacional", ou seja, de iniciativas que no sentido de, por meio do ensino, garantir os conhecimentos técnicos e os valores éticos necessários a um convívio harmonioso do homem com a natureza. A prioridade cabia ao campo, na medida em que "é principalmente no habitat rural que a Biogeografia tem de exercer sua atuação dinâmica, civilização, por isso que o habitat urbano se subordina ao urbanismo, universal". Desse modo, "as cidades são, por assim dizer, cosmopolitas, ao passo que dos sertões é que emana para o país o caráter nacional." ${ }^{41}$

Sampaio relata experiências e iniciativas pertinentes dos educadores ou das autoridades que pretendiam ensinar como amar e lidar com a terra e com os recursos naturais. Escolas que promoviam o aprendizado de práticas agrícolas, clubes de atividades rurais, ensino e práticas de reflorestamento, lições práticas de geografia e ciências naturais, Clubes Agrícolas Escolares, Clubes de Amigos da Natureza, Concursos Anuais

40 Idem, ibidem, pp. 24-25.

41 Idem, ibidem, p. 63 
de Plantas Vivas, distribuições de mudas florestais, cursos de proteção à natureza e uma pedagogia orientada para uma aproximação íntima da criança com a natureza. Tudo isso contribuiria para gerar um ambiente propício à defesa do patrimônio natural, ao mesmo tempo em que formava um cidadão, especialmente no campo, capaz de produzir a sua subsistência, mantendo o equilíbrio com a natureza.

O terceiro capítulo trata do "influxo dos poderes públicos" e procura delimitar as iniciativas que coubessem às instâncias governamentais. Sampaio assinalava que:

Em moldes científicos, criaram-se sucessivamente vários Hortos Botânicos, federais, estaduais e municipais, o Serviço Florestal do Brasil, os de Piscicultura e Reflorestamento do Nordeste, os de Colonização e Reflorestamento; foram decretados o Código Florestal, o Código de Caça e Pesca e a Lei de Expedições Científicas e Artísticas...

São as realizações mais recentes, que articuladas com as preexistentes e as visadas relativamente a minas, quedas dágua e código agrário, formarão o regime oficial de Proteção à Natureza no Brasil, de acordo com os mais modernos preceitos científicos. (Biogeographia, p. 78)

A proteção da natureza, porém, não devia ficar a cargo exclusivamente dos poderes públicos. Seria tarefa, também, de particulares. No quarto capítulo, sobre o "influxo das associações particulares", Sampaio tratava de dar visibilidade às realizações de indivíduos (empregados no serviço público ou livre empreendedores) e associações no Brasil que vinham contribuindo para a difusão das idéias e práticas relacionadas com a conservação da natureza. Com o propósito de valorizar aqueles que "agem objetivamente", lembrava que "dois nomes se apresentam em primeiro plano, pelas suas realizações de puro idealismo: o do Major Archer que reflorestou a Tijuca e o do professor Pedro Bruno que, em cada recanto magnífico e ao sopé de cada árvore majestosa, da linda Paquetá, instala uma inscrição protetora." 42 Além destes, eram mencionados os nomes de César Bierrenbach, pela comemoração anual da festa das andorinhas, em Campinas, e de Leôncio Corrêa, pela realização, desde 1903, em Paquetá (ilha dentro da baía de Guanabara), das festas das árvores e dos pássaros; de Antônio Prado e de Edmundo Navarro de Andrade, pelos plantios florestais da Companhia Paulista de Estradas de Ferro; de Coelho Neto e Augusto de Lima, por terem proporcionado, no Congresso Nacional, o ambiente que permitiu a criação do Serviço Florestal do Brasil; de Mariano Procópio, por ter criado, por iniciativa própria, um parque florestal em Juiz de Fora; de Catulo Cearense,

42 Idem, ibidem, pp. 83-84 
Monteiro Lobato, Roquete Pinto, Alberto Torres e Luiz Pereira Barreto, por seus escritos que contribuíram para gerar uma consciência favorável às iniciativas no campo da proteção à natureza.

No que se refere às associações civis, Sampaio mencionava várias que tinham tomado iniciativas de proteção à natureza: a Sociedade $\mathrm{Na}-$ cional de Agricultura, a Sociedade de Geografia do Rio de Janeiro, a Sociedade de Amigos de Alberto Torres, a Sociedade dos Amigos das Árvores, a Federação Brasileira pelo Progresso Feminino, o Touring-Club do Brasil, os Clubes de Escoteiros, a Funicular do Pão de Açúcar, algumas colônias estrangeiras - especialmente a colônia sírio-libanesa - e algumas empresas industriais - sobretudo a Companhia Paulista de Estradas de Ferro, pelos 10 milhões de eucaliptos plantados em São Paulo, por iniciativa do Conselheiro Antônio Prado e sob a direção de Edmundo Navarro de Andrade.

Por fim, Alberto Sampaio discorria sobre a imprensa brasileira, valorizando o que hoje chamamos a mídia. "Desde os maiores diários até os pequenos jornais escolares dos clubes agrícolas, pode-se dizer não há um que em suas colunas já não tenha impresso, uma vez pelo menos, a expressão 'Proteção à Natureza.'”43 Ele citava o Correio da Manhã (que publicara em fascículos a sua Phytogeographia do Brasil e o Sertão Carioca, de Armando Magalhães Correa), além dos trabalhos ilustrados do mesmo Corrêa e de Américo Novaes. Na imprensa paulista "verifica-se, por exemplo, a campanha de F. C. Hoehne, em favor das matas do Jaraguá." ${ }^{44}$ Nas revistas ilustradas, ele destacava a promoção de concursos de "Arte Fotográfica", estimulando a produção de ampla documentação sobre as belezas naturais do país.

Se no Brasil estavam se formando circunstâncias favoráveis à aceitação das idéias e práticas relacionadas com a proteção da natureza, nos foros internacionais a questão era discutida amplamente, há tempos. No quinto capítulo, desvendando o panorama global da questão, Alberto Sampaio mostrava a existência de um "Movimento Mundial" de proteção da natureza. Ele conhecia o que se passava no plano internacional e desejava que o Brasil se inserisse no que considerava ser uma "corrente" da proteção à natureza. Segundo ele, "cada país culto tem hoje suas leis acauteladoras de suas riquezas naturais, para que não se extingam, sendo que em relação às que infalivelmente se destinam à exaustão como as jazidas, essas leis estabelecem a conservação obrigatória de 'relíquias'", sendo que "quando se trata de sítios florísticos ou faunísticos, as relíquias têm mesmo a denominação de santuários de fauna e flora." Citava numerosos anais de congressos internacionais e

43 Idem, ibidem, p. 91

44 Idem, ibidem, p. 92.

152 VARIA HISTORIA, $\mathrm{n}$ 은 
publicações especiais pertinentes. ${ }^{45}$ Como sinal de integração do Brasil a esse "movimento internacional", Sampaio citava o Relatório da Primeira Conferência Brasileira de Proteção à Natureza, encontro do qual ele foi relator. ${ }^{46}$

No entanto, para ele não bastavam a pesquisa e a elaboração de leis e acordos internacionais. Segundo Sampaio, era necessária "a educação de cada pessoa, desde o lar e a escola primária, para evitar toda a ordem de malefícios, pois o essencial é evitar", pois "quanto mais adiantado o país, maior o influxo dos educadores nesse sentido, e quando adiantado como os Estados Unidos, até as Universidades publicam foIhetos." ${ }^{47}$

Para Sampaio, a proteção da natureza deveria ser obra de um Estado forte, capaz de integrar conhecimento técnico-científico, programas amplos de educação popular, e a força, quando necessário. A segunda parte da Biogeographia Dynamica pretendia ser uma "metodologia de ação". O ponto de partida se encontrava na crença de que:

O Brasil, país essencialmente agrícola, é noção que ninguém discute e todos os esforços devem ser feitos para que seja cada vez mais amplamente agrícola... A extensão de nosso território faz crer que, ainda mesmo que se multipliquem muito as cidades, bem como as indústrias, entre as quais a siderúrgica terá de ser a mais importante, nunca o Brasil perderá o conceito de país essencialmente agrícola. (Biogeographia, pp. 111-112)

A proposta era de que a prosperidade nacional se fundamentasse na pequena propriedade, subsidiada, do ponto de vista dos recursos técnicos e científicos, pela ação governamental. Com o objetivo de meIhorar e ampliar as áreas de cultivo, os campos de pecuária, as indústrias rurais, bem como o número e o âmbito das cidades, "o que apenas pede o setor da Proteção à Natureza, é que tudo isso se faça, conservando-se eternamente as 'Fontes da Vida no Brasil' e que por toda parte o ambiente seja lindo, uma vez que... nem só de pão vive o homem!"48

O programa de Sampaio para a proteção da natureza no Brasil ocupava três capítulos da segunda parte. No primeiro, tratava "das noções gerais da Biogeografia em sua feição dinâmica". Iniciava por definir a biogeografia como a "ciência que estuda a distribuição dos seres vivos", estruturada em três grandes ramos: fitogeografia, zoogeografia e antro-

45 Cf. SAMPAIO, Alberto. Biogeographia Dynamica, pp. 92-94.

46 Cf. FRANCO, José Luiz de Andrade, "A Primeira Conferência Brasileira de Proteção à Natureza e a questão da Identidade Nacional”, In: HORTA, Regina (org.), Revista Varia Historia, no 26, Dossiê História e Natureza Departamento de História UFMG, Belo Horizonte, 2002.

47 Cf. SAMPAIO, Alberto. Biogeographia Dynamica, p. 96.

48 Idem, ibidem, p. 112. 
pogeografia. ${ }^{49}$ Esses ramos se complementariam em uma síntese, que permitiria entender a natureza e usufruir de todos os seus benefícios, sem prejudicá-la, preservando-a, e admirando-Ihe as belezas: "Eis a questão, prática por excelência, a finalidade dos estudos que precisamos metodizar, em relação ao Brasil, tendo por base os ensinamentos dos países que, antes de nós, já metodizaram essa prática."50

Sampaio acompanhava os congressos internacionais através das publicações do Ofício Internacional para a Proteção da Natureza (OIPN) e propunha o estabelecimento de normas universais, sem prejuízo de adaptações às condições de cada país. Ele considerava importante: 1) impedir o rareamento ou a extinção os bens naturais, sujeitos a consumo e passíveis de multiplicação; 2) cuidar de sítios e paisagens, em benefício do turismo e do excursionismo; 3) assegurar a perpetuidade de espécies animais e vegetais, bem como das curiosidades geomorfológicas, de interesse científico, em seu estado natural; 4) evitar danos às quedas d'água, aos mananciais e a outras produções naturais merecedoras de conservação permanente; 5) melhorar a natureza, onde necessário. Sugeria ainda que se implementassem 1) um cadastro dos monumentos naturais do país; 2) reservas naturais, de interesse científico e técnico; 3) parques nacionais de uso público; 4) repovoamento animal e vegetal. ${ }^{51}$ Sampaio citava 62 congressos, realizados entre 1884 e 1935em todo o mundo, nos quais esses temas haviam sido debatidos.

O segundo capítulo da segunda parte da Biogeographia Dynamica trata justamente de "proceder a uma discussão sobre o cadastro dos Monumentos Naturais". Nele, Sampaio propunha uma classificação deles, explicando que:

A designação "Monumento Natural" é reservada às produções naturais de excepcional interesse e que por isso devem ser permanentemente conservadas: árvores seculares, históricas ou legendárias, megalitos, grutas, quedas dágua, sítios de grande beleza, florestas protetoras, tipos regionais de vegetação, espécies raras, jazidas, remanescentes etnográficos, etc. (Biogeographia, p. 70)

Sampaio entendia que motivos mais pragmáticos também justificariam um cadastro dos "monumentos naturais" no Brasil, sendo o principal deles o turismo, que vinha se desenvolvendo no país. Isso acabaria por tornar imperioso a criação de um "Bureau Oficial de Monumentos Naturais", dotado de uma equipe de cientistas. ${ }^{52}$ Sugeria um esforço concer-

\footnotetext{
49 Idem, ibidem, p. 113.

50 Idem, ibidem, p. 115.

51 Idem, ibidem, pp. 115, 130

52 Idem, ibidem, p. 132.

53 Idem, ibidem, p.133.
}

154 VARIA HISTORIA, $\mathrm{n} \div 33$ 
tado e de grande amplitude, envolvendo vários ramos do governo. O Ministério da Educação deveria formar um "Bureau de Monumentos Naturais". O Ministério da Agricultura deveria ser incumbido de fazer o cadastro florestal, enquanto o Ministério da Fazenda cuidaria de cadastrar os "Monumentos do Domínio Público". Os Ministérios da Guerra e da Marinha deveriam arrolar os monumentos sob a sua jurisdição. Cada Estado e cada município deveria cogitar de discriminar e proteger os seus monumentos. ${ }^{53}$ Assim a proteção à natureza, além de ser um programa da sociedade e do governo, deveria mobilizar o governo de uma forma que podemos, também sem anacronismo, denominar de "transversal", envolvendo diferentes setores da sociedade e do poder público.

O terceiro e último capítulo da segunda parte da Biogeographia Dynamica, intitulado "Proteção à Natureza: Preceitos e Legislação", ocupa mais da metade do livro e subdivide-se em oito itens: "Solo e Subsolo", "Primores Florísticos", "Primores Faunísticos", "Indígenas e Sertanejos", "Sítios e Paisagens", "Turismo", "Subsídios Acessórios", e "Legislação Brasileira".

Para contextualizar o exame desses regulamentos, Sampaio coligiu "nos relatórios dos Congressos Internacionais de Paris em 1923 e 1931, e em várias outras publicações, todas as instituições e serviços, oficiais ou particulares, que de qualquer modo têm influído." ${ }^{4} 4$ Sampaio citava, além de toda uma extensa série de congressos (nacionais e internacionais) e do Ofício Internacional para a Proteção da Natureza, bureaux ou serviços ministeriais, universidades, academias de ciência e associações particulares de todo tipo. A sua conclusão era de que havia uma certa universalização das preocupações relacionadas com a proteção da natureza. ${ }^{55}$

A proteção da natureza, definida como ciência, devia ser capaz de proporcionar conhecimentos que auxiliassem o homem a evitar as devastações e viver em harmonia com o seu meio. Dessa forma, Sampaio considerava que, fruto de estudos científicos, "a legislação especial, hoje existente em todos os países cultos, focaliza os preceitos adequados a cada país em cada época, enquanto que os congressos visam essencialmente regras atinentes a minúcias e novos preceitos, ainda não previstos em lei." Concluía que havia a necessidade de desenvolver duas ordens de atividades "paralelas" e "harmônicas": 1) a atividade dos poderes públicos (serviços oficiais, de fiscalização das leis; grandes realizações, parques nacionais, reservas naturais, estações biológicas, etc.; bureau ou serviços especiais de monumentos naturais; educação nacional e legislação); e 2) a iniciativa particular, realizando o que puder, ao

54 Idem, ibidem, p. 153

55 Idem, ibidem, p. 165.

Janeiro, 2005155 
mesmo tempo que nada destruindo daquilo que for do interesse nacional. ${ }^{56}$

Segundo Sampaio, o ponto de partida para a realização da proteção à natureza devia ser o preceito de que "tudo deve ser feito para evitar a aplicação de penalidades, pois estas só se impõem após malefícios; só a educação popular, amplamente disseminada por todos os modos úteis, pode evitar as infrações, por ignorância; as que forem determinadas por simples cobiça ou egoísmo, são justamente as que se destinam a ser rigorosamente punidas." ${ }^{7} 7$ Além das leis recentes, Sampaio defendia uma "ampla cruzada educacional", com o objetivo de conscientizar a população de que os recursos naturais não eram inesgotáveis e de que as iniciativas de proteção à natureza não se opunham à produção e ao progresso.

Sampaio refletia, também, sobre a necessidade de uma política de "grandes realizações", que objetivasse a preservação do patrimônio natural por meio da criação de "parques nacionais", "reservas naturais" e "estações biológicas", submetidos ao mencionado bureau a ser criado no Ministério da Educação. ${ }^{58}$

O segundo item trata dos "Primores Florísticos", que precisavam ser protegidos contra a tendência humana a "uniformizar e tornar monótona a paisagem", privando-a da diversidade de espécies característica de cada região geográfica. Assim, "a propósito da flora de cada país, a Proteção à Natureza tem em vista o duplo objetivo de manter os respectivos primores vegetais e pelo menos relíquias de formações ou associações florísticas, típicas, de interesse biológico ou fitogeográfico". Sampaio considerava que, "praticamente, a forma de fato eficiente de proteger a flora é a instituição de Reservas Naturais, de que as adaptáveis ao turismo, devem ser colocadas sob o regime de Parques Nacionais, isto é, sob o regime de exploração turística, devendo ficar sob o controle de um instituto científico." 59

O terceiro item trata dos "Primores Faunísticos", que se beneficiariam das providências tomadas para proteger a flora. Dessa maneira, "a criação de Reservas Florísticas e Parques Nacionais atende a necessidade que tem a fauna útil de refúgios, onde possa viver à vontade, livre de perseguições de toda ordem." 60

Nesse ponto, Sampaio faz uma discussão interessante sobre as questões da raridade das espécies de animais e plantas e da sua utilidade ou nocividade. Ele considerava importante uma catalogação das espécies raras, considerando o tipo de raridade (local, regional, ou mesmo o peri-

\footnotetext{
56 Idem, ibidem, pp. 170-171

57 Idem, ibidem, p. 172.

58 Idem, ibidem, p. 173.

59 Idem, ibidem, pp. 194-195

60 Idem, ibidem, p. 199.
} 
go de extinção), para que se tomassem as medidas adequadas à sua preservação. É uma proposta precursora das listas oficias de animais e plantas ameaçados de extinção, a primeira das quais foi editada no Brasil apenas em fins da década de 1960.

Outra questão fundamental para Sampaio é tratada no quarto item, "Indígenas e Sertanejos". Nele se discute o tipo de ação que afetaria esses homens que viviam em contato mais próximo com o mundo natural. O pressuposto era que "O homem também é parte da natureza e onde ele exista em estado rústico, é um dos elementos naturais do habitat respectivo, mas a proteção que sugere ou precisa, é bem diversa da proteção à natureza em geral" ${ }^{61}$

Sampaio afirmava sem rodeios que indígenas e sertanejos deviam ser beneficiados e integrados pela "civilização". Precisavam ser educados, embora de forma paulatina, pois seriam necessários muitos anos para que abandonassem os seus "hábitos" e "tabus". Por outro lado, a cultura deles tinha um valor histórico e contribuía para diversificar os "encantos da vida humana". Segundo Sampaio, "a educação dos indígenas e sertanejos, sob o prisma da disciplina que nos ocupa, tem o duplo fim de proporcionar-Ihes na Natureza a fartura permanente de meios de subsistência e impedir que sejam eles (íncolas e sertanejos) eternos fatores de destruição da Natureza." Era fundamental garantir uma escola rural capaz de proporcionar ao homem do campo o acesso ao melhor que a "civilização" podia lhe oferecer, tanto para o desenvolvimento quanto para a proteção da natureza nos sertões. Desse modo, "as populações rurais, íncolas e sertanejos, interessam à Proteção à Natureza, ou à Biogeografia humana, nessa parte relativa à melhoria do habitat, sem prejuízo do fácies natural de cada região." 62 Assim, Sampaio estava longe da caricatura de "insensível" aos direitos e virtudes do que chamamos hoje de "populações tradicionais", embora não compartilhe das formulações atuais que as defendem como inerentemente preservacionistas, conservacionistas ou ambientalistas.

Com relação ao quinto item, "Sítios e Paisagens", Sampaio observa que alguns países os incluíam no título geral de Monumentos Naturais, enquanto outros consideravam-nos separadamente. Da mesma forma, alguns países subordinavam as florestas à agricultura, enquanto outros tinham Ministérios de Agricultura e Florestas. ${ }^{63}$ Sampaio considerava que os sítios e paisagens, sobretudo nos países tropicais, dependiam estreitamente das árvores e das florestas, os seus principais componentes. Outros motivos, porém, determinavam a individualização dessas entida-

61 Idem, ibidem, p. 210.

62 Idem, ibidem, pp.210, 212.

63 Idem, ibidem, p. 241. 
des, essencialmente turísticas, nos cadastros dos países que tinham organizado a proteção aos seus bens naturais. Era, então, urgente uma lei que definisse as normas de conservação dos "Monumentos Naturais". As leis de países como França, Japão e Luxemburgo eram apresentadas como exemplos a serem seguidos. O importante era que se começasse por "criar, onde conveniente, o cadastro de Sítios e Monumentos Naturais e irmos a pouco e pouco sistematizando o assunto; quanto mais tempo demorarmos a criar esse serviço, tanto pior." 64

A necessidade de um cadastro de "Monumentos Naturais" estava relacionada, também, ao sexto item discutido por Sampaio - a questão do "Turismo", considerado como "uma das forças mundiais mais influentes na proteção à natureza". A fórmula ideal para a preservação da natureza, capaz de gerar uma arrecadação suficiente para a sua manutenção, seria a criação de parques nacionais espalhados por todos os municípios do país. Isso proporcionaria uma ampla rede turística, geraria divisas e empregos e garantiria a conservação do patrimônio natural.

Chama a atenção, em toda esta argumentação de Alberto José Sampaio, a percepção, já naquela época, de que a questão da conservação da natureza devia ser uma preocupação presente em todas as esferas e níveis de governo, o que hoje tem sido bastante difundido por intermédio do conceito de "transversalidade". A ênfase na educação é outro aspecto notável do seu pensamento. Por último, a idéia de que cabia à iniciativa privada uma parcela substantiva de iniciativas no campo da proteção à natureza é outro aspecto curioso e interessante do pensamento de Sampaio. Ela relativiza, um pouco, a sua crença na necessidade de um Estado forte e centralizador.

\section{6 - Considerações finais}

As obras de Alberto Sampaio expressaram um projeto que relacionava a proteção da natureza à questão da identidade nacional. A elaboração desse projeto envolveu a apropriação e articulação de diversas tradições de pensamento: especializações no campo da biologia (ecologia, biogeografia etc.), a visão romântica de natureza, ideais preservacionistas e conservacionistas de cuidado com o mundo natural, interpretações sociológicas e literárias da sociedade brasileira (com destaque especial para a obra de Alberto Torres). Estas perspectivas convergiram para uma concepção organicista de mundo, na qual o homem e a natureza apareciam reconciliados. Como outros pioneiros de sua época, Alberto José Sampaio desbravou caminhos intelectuais e institucionais que

64 Idem, ibidem, p.245. 
ajudaram a colocar a proteção à natureza na agenda pública e na consciência social brasileiras. Como outros cientistas conservacionistas, frustrou-se ao perceber que suas preocupações com a proteção da natureza, embora em sintonia com o discurso cientificista e nacionalista em voga, eram pouco relevantes para os interesses hegemônicos na estrutura do Estado e da sociedade. A coalizão de poder formada em 1930 se revelou solidamente desenvolvimentista, no sentido menos "ambiental" que o termo pode assumir. Mesmo sofrendo diversas modificações em 1937, 1945 e 1964, o desenvolvimentismo oficial brasileiro expressou uma visão largamente disseminada na sociedade de que o crescimento econômico deveria ser perseguido a todo custo, inclusive, mas não exclusivamente, os custos ambientais. Isso fez com que as vozes de Sampaio e dos conservacionistas seus contemporâneos fossem em grande parte abafadas pela agitação feérica das grandes obras públicas e das grandes unidades produtivas do industrialismo moderno, levando à ampla insuficiência, durante muitas décadas, das medidas adotadas no sentido de conservar ou proteger a natureza.

Os imperativos da ciência não foram ouvidos no processo de "reorganização" e desenvolvimento do Brasil dos anos 1930-1980. Nessas décadas, a natureza, "fonte da vida", na verdade, contou pouco na constituição da "identidade nacional". Não surpreende que Sampaio e contemporâneos tenham sido quase esquecidos na correnteza forte do "desenvolvimento a qualquer custo" das décadas de 1940 em diante. Surpreende mais que eles tenham sido quase esquecidos pelos ambientalistas brasileiros — tanto os "científicos" quanto os "sociais" — que, a partir da década de 1980, emergiram como atores relevantes em muitas arenas da ciência, do ativismo, da mídia, dos governos e dos movimentos sociais. 